DOI: 10.22616/REEP.2021.14.022

\title{
The Independence of Primary School Students in Learning Music at a Distance During Covid-19 Pandemic
}

\author{
(D)Ligita Stramkale Dr. paed. \\ University of Latvia, Latvia \\ ligita.stramkale@lu.lv
}

\begin{abstract}
As a result of the Covid-19 pandemic, the primary school students were forced to study at a distance of two and a half months starting from mid-March 2020. There was a situation where students had to learn music independently more than they had done so far. The study aims to determine 2 nd and 3rd grade students' perspectives on independent distance learning of music during the Covid-19 pandemic. To achieve the aim of the study, previous researches on this issue were analysed, as well as an empirical study was carried out. The study involved $105(\mathrm{~N}=105)$ primary school students in grades 2-3 and occurred in the second term of the 2019/2020 school year in a public primary school located in Riga. A questionnaire consisting of 20 statements was conducted to determine students' perspectives on music distance learning independently. The twenty statements were divided into four groups: students' independence, provision of technical aids, difficulties and attitude. The study revealed that the students' skills to find and complete the tasks that are given by the teacher in the E-class are at a middle level. The students assessed their ability to learn to sing songs and perform music listening tasks independently at a high level. The students mostly used computers or mobile phones when they learned music at a distance. However, the majority of students faced a lack of technical aids. The study found out that complete music listening task was the easiest for the students, but a little harder was learning to sing songs. The most difficult part of learning for students was to complete a writing task because the possibility of printing it was limited. The students rated their attitude towards music distance learning independently at a middle level. Many students missed the presence of their teachers and longed for social activities in the classroom. The study concluded that there is a significant difference between 2 nd and 3rd grade students' skills to find independently the tasks sent by the teacher. Moreover, the 3rd grade students wanted to learn music independently at a distance more than the 2 nd grade students did. The study provides evidence-based data on primary school students' readiness to learn music independently at a distance.
\end{abstract}

Keywords: distance learning, independence, music lesson, primary school student, school education.

\section{Introduction}

At the beginning of 2020, the education system faced many challenges in the transition to distance learning. One of the challenges was to teach children how to find the tasks independently, complete them, and send them back to their teacher. During the Covid-19 pandemic, the teacher had to find a way to support students to learn at a distance. In the spring of 2020, it was reported in mass media that students' distance learning is hindered by the lack of computer and internet access and the lack of independent work skills and motivation (Medne, 2020). On the other hand, in distance learning, the teachers have to cope with a much more intense workload. They need to respond more flexibly to the new situation, manage their time, prepare appropriate teaching materials, and deal with technical problems (Opincāne, 2020). It means that independent distance learning caused a problem for students and created additional stress for teachers.

To understand better why independent learning can be difficult for students, let us analyse the meaning of independent learning. Independent learning can be defined as a learning approach in which students are encouraged to be self-regulated learners (Wallace, 2015), or as a mode of learning in which the learner in some way is working independently of a teacher (Lamb, 2006). It is considered as a process, method and philosophy of education by which the learner acquires knowledge and develops cognitive and critical assessment skills on his/her own (Candy, 1991). Independent learning can be difficult for primary school students because they cannot get the teacher's support immediately and have to deal with a wide range of situations on their own.

Independent learning is related to the ability to set learning goals, organize and manage learning activities (Zheng et al., 2020). It is inconceivable without responsibility. B. Meyer and colleagues 
believe that responsibility includes understanding one's learning, motivation to learn and cooperating with the teacher (Meyer et al., 2008). Independent learning is about making a responsible decision. The student is expected to analyse the problems encountered, reflect on his/her learning, make decisions, and take purposeful actions (Kopzhassarova et al., 2016).

Distance learning has become more topical during the Covid-19 pandemic as an alternative to the traditional educational process. I. Katane and colleagues concluded that since the 18 th century, when the first attempt of distance education had been registered, until nowadays the humankind has amassed a rich experience in this sphere (Katane, Katans, Vavere, 2012). Independent learning is a process in which regulating the learning process and controlling it are undertaken by the students themselves (Balapumi, Aitken, 2012). Learning independently students manage their time by following their learning process without needing teachers or parents' assistance (Darnis, 2020). For students to manage their time as efficiently as possible, they should start to perform the task without delay, do it with pleasure, and do not deal with side things. E.L. Deci and R.M. Ryan understand independence as acting alone and not relying on others (Deci, Ryan, 2008). R. Balapumi and A. Aitken, in turn, describe independent learning as proactive, self-motivated, and resourceful learning (Balapumi, Aitken, 2012).

Independent learning is not only just about students learning on their own and giving them more independence but also the teacher should be involved in the learning process as well. Several researches have also provided evidence of the effectiveness of teacher involvement in the process of learning independently. For example, M. Cukurova and colleagues (Cukurova, Bennett, Abrahams, 2018) studied the effectiveness of guided independent learning and unguided independent learning. The study revealed that guided independent learning improves the knowledge and skills required to deal with new situations. In turn, unguided independent learning leads to an increase in the number of mistakes in the task. The researchers concluded that counselling and extra support are also needed to enable students to learn independently. P. Hughes also believes that independent learning should be complemented by contact, support and training that provided by the teacher (Hughes, 2014). Moreover, M. Gorman emphasizes the need for the teacher to think about learning stages and learning outcomes (Gorman, 1998).

Independent learning is facilitated by formative feedback (Issa, Issa, Kommers, 2014), creation of e-portfolios (Chau, Cheng, 2010), and proper organization of independent work (Kopzhassarova et al., 2016). The researchers also believe that students' independent learning is influenced by self-regulated learning (Sukowati, Sartono, Pradewi, 2020) and internal motivation or desire to learn without the support of another person (Deci, Ryan, 2008). If students have a lack of interest in the learning activities, they will need external stimuli and other assistance to learn independently.

The question is whether primary school students can learn independently. D. Whitebread and colleagues (Whitebread et al., 2005), while studying the development of independent learning for preschool children aged 3-5, concluded that even at this age children can learn independently. On the other hand, L. Sze Yean, when analysing the promotion of active and independent learning in primary education, acknowledged that it is important for students to learn independently as opposed to listening and absorbing the information presented by the teachers (Sze Yean, 2019). To learn independently, students should have the ability to supervise their learning process. This, in turn, helps to perform a certain task and achieve the goal.

Music is one of the subjects that must be acquired in primary school. Face-to-face making music is often collective work. In the face-to-face music lessons, the students are singing together, playing music instruments, improvising, making rhythm in a little group or sometimes individually. L. Thornton believes that learning music at a distance prevents the collective work needed to make music because "there is currently no technological way to make music together, in real time, in distance locations" (Thornton, 2020,6). This means that when performing musical activities at a distance, the students mostly have to do it individually. It is hard because the ability to make music individually requires appropriate musical experience and many skills. L. Ritchie and A. Williamon studied primary school students' self-efficacy in learning music. The analysis of children's previous musical experiences, outof-school and daily musical activities provided the researchers with the conclusion that students who play a musical instrument or sing daily have significantly higher self-efficacy rates than those who do not play music outside the classroom (Ritchie, Williamon, 2011). Furthermore, E. Shieh and R.E. Allsup considered that making music independently is closely connected with acquiring the skills needed. It is 
the student's desire for something unexpected, for something that teachers are not able to predict, measure or compare. Independent music making provides students with the opportunity to sing or play a musical instrument even after school (Shieh, Allsup, 2016).

Independent and distance learning requires not only musical experience and a variety of skills but also creating an environment conductive to learning. Learning is facilitated by the physical environment and learning resources (Meyer et al., 2008). A study conducted by R.L. Martens and colleagues (Martens, Valcke, Portier, 1997) concluded that the impact of an interactive learning environment on independent learning is not less effective than printed learning materials or face-to--to-face lessons.

Due to the Covid-19 pandemic an unprecedented but significant experience is acquired. So far, the nature of independent learning has been studied in the context of face-to-face lessons more than in the context of distance learning. The analysis of primary school students' independence in learning music at a distance is insufficient. It is also essential to understand how primary school students themselves feel when learning music independently at a distance. That determined the aim of this study.

The study aims to determine 2nd and 3rd grade students' perspectives on independent distance learning of music during Covid-19 pandemic.

\section{Methodology}

The study was carried out in the second term of the 2019/2020 school year in a public primary school located in Riga. The study included $105(\mathrm{~N}=105)$, second $(\mathrm{N}=47)$ and third $(\mathrm{N}=58)$ graders consisting of 73 girls $(\mathrm{N}=73)$ and 32 boys $(\mathrm{N}=32)$.

The study seeks to answer the following five research questions:

- How independent are students during learning music at a distance?

- What technical teaching aids do students use to learn music at a distance?

- What difficulties do students have in music distance learning?

- What is the students' attitude towards music distance learning independently?

- Is there a difference between 2 nd and 3rd grade students in learning music independently at a distance?

A questionnaire consisting of 20 statements was conducted to answer the questions raised in the study. The second and third graders were asked to assess each statement using a 4-points Likert scale. The questionnaire was anonymous and the results were analysed as a whole. The time given to complete the questionnaire was not limited. For data processing, the response variants were recoded into digits: 4 -always, 3 - often, 2 - rarely and 1 - never. To determine the level of students' independence in music distance learning, the 4-points Likert scales were divided into three levels. If the arithmetic mean ranges from 1.00 to 2.00 , it is a low level, if it ranges from 2.01 to 3.00 , it is a middle level and if it ranges from 3.01 to 4.00 , it is a high level.

The statements used in the study were categorized into four groups. The first group determined students' independence in learning music at a distance. The second group identified what technical aids students use in learning music at a distance. The third group revealed the types of musical activities that are more difficult for students to learn independently at a distance. In turn, the fourth group determined the students' attitude towards music distance learning independently.

The quantitative results were analysed using the Statistical Package for the Social Science (SPSS) version 22 data processing software. The Cronbach's Alpha coefficient was calculated to determine the internal consistency, reliability and the validity of the questionnaire statements. The arithmetic mean $(\mathrm{M})$, standard deviation (SD), standard deviation error (SE), and the median (ME) were calculated for each statement of the study. The median (ME) describes the significance of the variable, and by comparing it with the arithmetic mean (M) determines whether the data collected in the study is symmetric or asymmetric. To determine the normality of each variable, the Skewness and the Standard Error of Skewness were used. If the Skewness ranges from -0.5 to 0.5 , it means that the collected data is fairly symmetrical if it is from -1 to -0.5 or from 0.5 to 1 , it shows that the data is moderately skewed, and if it less than -1 or more than 1 , then it is highly skewed. The Bivariate (Pearson) correlation analysis was used to examine the reliability of the responses. The correlation coefficient has statistically 
significant sigma of 0.01 and 0.05 . To determine whether there is a significant difference between $2 \mathrm{nd}$ and 3rd grade students' independence in distance learning of music ANOVA was used.

\section{Results and Discussion}

The consistency and reliability of the questionnaire statements are sufficient $(\mathrm{a}=0.489)$ to analyse the students' independence in learning music at a distance, the provision of technical aids needed for learning, the difficulties encountered while learning music, as well as the students' attitude towards music distance learning independently.

Independent learning is an essential part of distance learning. For students to be able to perform the assigned tasks in music independently, they must have many skills, such as the ability to find the task, complete it and send it back to the teacher. The study found (Table 1) that the students, at a middle level, could find the assigned tasks in E-class by themselves $(\mathrm{M}=2.66 ; \mathrm{SD}=1.173)$, complete the writing tasks independently $(\mathrm{M}=2.88 ; \mathrm{SD}=0.923)$ and send it to the teacher $(\mathrm{M}=2.06 ; \mathrm{SD}=1.195)$. The study also revealed that there is a difference between 2 nd and 3rd students' skills to find the assigned music tasks in the E-class $(\mathrm{F}=6.94, \mathrm{p}=0.010<0.05)$. If the students find the music tasks in the E-class, they will learn to sing songs $(r=0.431 ; p<0.01)$, perform music listening tasks independently $(r=0.290 ; p<0.01)$ and will be able to send the completed tasks to the teacher $(\mathrm{r}=0.530 ; \mathrm{p}<0.01)$. Besides, if students find the tasks in E-class by themselves, they will have no problem learning music at a distance by using technology $(r=0.242 ; p<0.01)$, their parents will be less involved in the music learning process $(r=0.303 ; p<0.01)$ and they will learn music more $(\mathrm{r}=0.267 ; \mathrm{p}<0.01)$.

Table 1

Independence in learning music at a distance

\begin{tabular}{|l|c|c|c|c|c|}
\hline \multicolumn{1}{|c|}{ Statements } & M & SD & SE & ME & Skewness \\
\hline I could find the tasks in E-class by myself & 2.66 & 1.173 & 0.114 & 3.00 & -0.265 \\
\hline I performed the writing tasks independently & 2.88 & 0.923 & 0.090 & 3.00 & -0.367 \\
\hline I learned to sing songs independently & 3.22 & 0.912 & 0.089 & 3.00 & -0.938 \\
\hline I listened to music and performed related tasks independently & 3.13 & 0.866 & 0.084 & 3.00 & -0.751 \\
\hline I could send the completed task to the teacher in E-class & 2.06 & 1.195 & 0.116 & 2.00 & 0.627 \\
\hline I learned music a lot by myself & 2.50 & 0.914 & 0.191 & 2.00 & 0.021 \\
\hline My parents helped me to learn music & 2.71 & 1.080 & 0.105 & 3.00 & -0.244 \\
\hline
\end{tabular}

The students assessed their ability to learn to sing songs independently $(\mathrm{M}=3.22 ; \mathrm{SD}=0.912)$ and perform music listening-related tasks $(\mathrm{M}=3.13 ; \mathrm{SD}=0.866)$ at a high level. If the students can learn to sing songs independently, it will not be difficult for them to learn these songs $(r=0.243 ; p<0.01)$. The study found that there is a relationship between the students' ability to perform writing tasks independently and their ability to sing songs by themselves $(\mathrm{r}=0.283$; $\mathrm{p}<0.01)$ as well as to complete music listening tasks $(\mathrm{r}=0.452$; $\mathrm{p}<0.01)$. In this case, the parents' involvement was not necessary because the students themselves could learn music at a distance $(\mathrm{r}=0.255 ; \mathrm{p}<0.01)$. The parents would involve in music distance learning if the students could not complete the writing task $(\mathrm{r}=0.332 ; \mathrm{p}<0.01)$ or if the students did not want to devote much time for performing the tasks $(\mathrm{r}=0.301 ; \mathrm{p}<0.01)$. The students assessed the assistance of their parents during distance learning of music at a middle level $(\mathrm{M}=2.50 ; \mathrm{SD}=1.080)$. At the same time, the median and skewness scores $(M=2.00$; Skewness=0.021) allow concluding that the results obtained are highly skewed, which in turn indicates that there were some students whose parents were more involved in learning music and others who have not got any assistance from parents.

Independent distance learning of music is unthinkable without motivation to learn at a distance, insistence and non-surrender in difficult moments. Moreover, S. Darnis, who studied the impact of 1 st grade students' independent learning on achievement in learning English, admits that independent learning is related to interest in the learning process, the immediate focus on performing the tasks and the insistence during performance (Darnis, 2020).

When learning music at a distance, students must be adequately equipped with technical aids. The students admit that they are learning music at a distance mostly by using mobile phones and computers, but the minority of them use tablets (Table 2). The study determined that there is significant different between 2 nd 
and 3rd grade students in how often they use tablets in distance learning of music $(\mathrm{F}=6.32, \mathrm{p}=0.013<0.05)$. Besides, the median and skewness scores $(\mathrm{ME}=1.00$; Skewness $=-0.891)$ provide an opportunity to conclude that the results obtained are moderately skewed, which in turn indicates that some students mainly use tablets only for learning music, but some students either do not have tablets at all or do not use them for learning.

After starting distance learning of music, many questions were asked by teachers and parents appeared in social networking sites and media about the possibility of learning music at a distance. The authorities responsible for education offered solutions. One of the solutions that help teachers ensure distance and independent learning of music in primary education was the creation of an educational TV program "Your Classroom". The study revealed that during the Covid-19 pandemic, the primary school students did not sufficiently use the opportunity to learn music through the offered TV program ( $M=1.40 ; \mathrm{SD}=0.872)$.

Table 2

Providing students with technical aids for learning music at a distance

\begin{tabular}{|l|c|c|c|c|c|}
\hline \multicolumn{1}{|c|}{ Statements } & M & SD & SE & ME & Skewness \\
\hline I was able to print the task & 1.87 & 1.214 & 0.118 & 1.00 & 0.898 \\
\hline I learned music with the help of a computer & 2.34 & 1.239 & 0.120 & 2.00 & 0.214 \\
\hline I learned music with the help of a tablet & 1.89 & 1.216 & 0.118 & 1.00 & 0.891 \\
\hline I learned music with the help of a mobile phone & 2.38 & 1.296 & 0.126 & 2.00 & 0.200 \\
\hline I learned music with the help of TV programs & 1.40 & 0.872 & 0.085 & 1.00 & 2.216 \\
\hline I had a lack of technical aids to learn music & 1.81 & 1.026 & 0.100 & 1.00 & 0.862 \\
\hline
\end{tabular}

The students assessed the possibility to print the assigned music tasks at a low level $(M=1.87 ; \mathrm{SD}=1.214)$. Furthermore, the students think that they have not been provided with the needed technical aids for distance learning $(\mathrm{M}=1.81 ; \mathrm{SD}=1.026)$. On the other hand, those students who had the opportunity and were able to print the page needed to complete the writing task could easily send it back to the teacher $(r=0.397 ; \mathrm{p}<0.01)$. The students who learned music at a distance using a mobile phone or a tablet, admitted that they did not have the opportunity to print the teaching material sent by the teacher $(r=0.348 ; \mathrm{p}<0.01)$. It is interesting to note that those students who were able to print the assigned music tasks from the E-class, felt that they would like to continue learning music at a distance $(r=0.266 ; p<0.01)$.

The shortage of technical aids during independent learning of music at a distance has a significant impact on performing the writing tasks $(r=0.331 ; \mathrm{p}<0.01)$, learning to sing $(\mathrm{r}=0.430 ; \mathrm{p}<0.01)$ and listening to music $(r=0.316 ; \mathrm{p}<0.01)$. Insufficient technical aids do not motivate students to learn music. Because of that, the students spend less time on independent distance learning of music $(r=0.354 ; p<0.01)$, and the parents cannot help children if there is a lack of technical aids in the family $(r=0.222 ; \mathrm{p}<0.01)$.

Researchers also acknowledge the advantages of using technical aids in the music learning process. For example, R. Upitis and colleagues have determined that music teachers value the use of digital tools (Upitis, Abrami, Boese, 2016) as they help to achieve musical success (Upitis, Boese, Abrami, 2017). D. Wicks points out that the key to learning through technology is to create more accessible, new and better forms of learning (Wicks, 2008). However, T.C. Reeves thought that the computer cannot compensate the students' lack of musicality, but it can help them to maximize their musical abilities to be applied in a new and challenging context (Reeves, 1998). Technical aids are essential for successful independent music learning. The third group of statements identified the difficulties encountered while learning music independently at a distance. The obtained results are presented in Table 3.

Table 3

Difficulties faced by students during independent learning of music at a distance

\begin{tabular}{|l|c|c|c|c|c|}
\hline \multicolumn{1}{|c|}{ Statements } & M & SD & SE & ME & Skewness \\
\hline I had difficulty in completing the writing tasks & 2.36 & 0.931 & 0.090 & 2.00 & 0.231 \\
\hline It was hard for me to learn to sing songs & 2.14 & 0.974 & 0.095 & 2.00 & 0.405 \\
\hline I had trouble in completing music listening-related tasks & 1.67 & 1.004 & 0.098 & 1.00 & 1.329 \\
\hline I felt the need for the presence of a teacher & 2.97 & 1.130 & 0.100 & 3.00 & -0.676 \\
\hline I spent much time learning music independently at a distance & 2.26 & 1.111 & 0.108 & 2.00 & 0.265 \\
\hline
\end{tabular}


The students believed that completing the writing tasks was the most challenging part of learning $(\mathrm{M}=2.36 ; \mathrm{SD}=0.931)$. If it is difficult for the students to complete the writing tasks independently, they will spend more time for that $(\mathrm{r}=0.355 ; \mathrm{p}<0.01)$ and will need assistance from their parents $(\mathrm{r}=0.331$; $\mathrm{p}<0.01$ ). In turn, if the students had difficulty to sing songs independently, they would have a problem with listening to music and performing the related tasks as well $(r=0.381 ; \mathrm{p}<0.01)$. In addition, they were not provided with the needed technical aids $(\mathrm{r}=0.430 ; \mathrm{p}<0.01)$, they spent much time to learn music independently $(r=0.355 ; \mathrm{p}<0.01)$ and needed parents' assistance $(r=0.331 ; \mathrm{p}<0.01)$.

The students thought that the easiest for them was to complete music listening related tasks. It should be noted that the data obtained in this statement are moderately skewed, which indicates that some students were able to perform tasks related to listening to music easy but the other faced lots of difficulties and even they could not cope with the task at all $(\mathrm{ME}=1.00$; Skewness=1.329). The study found that if students had problems with completing a task related to listening to music, then they did not spend much time on that and did not ask parents for help. It was because the students have not got the needed technical aids for learning $(r=0.316 ; \mathrm{p}<0.01)$, as well as the fact that they had difficulties with learning other types of musical activities independently.

Most students felt the importance of teacher presence while learning music at a distance $(\mathrm{M}=2.97$; $\mathrm{SD}=1.130$ ). The presence of the teacher is an important part of the learning process. Distance music learning cannot ensure the physical presence of the teacher, but the students must feel the support of the teacher. B. Meyer and colleagues also believe that independent learning is not only meaning that students are learning alone, but the teacher must promote and support the process of independent learning (Meyer et al., 2008). How can the teacher support and promote students independent learning? In determining the students' opinions about what kind of support from the teacher they need during distance learning, T. Lamb concludes that it is essential for the students that the teacher helps them to understand how to learn independently (Lamb, 2006). The students' attitude towards independent distance learning of music is confused and uncertain (Table 4). The study revealed that some 2 nd and 3rd grade students enjoyed learning music independently at a distance, while other students had great difficulty to do that on their own and could not wait to return to school $(\mathrm{ME}=1.00$; Skewness= 0.591).

Table 4

Students' attitude toward independent distance learning of music

\begin{tabular}{|l|c|c|c|c|c|}
\hline \multicolumn{1}{|c|}{ Statements } & M & SD & SE & ME & Skewness \\
\hline I enjoyed learning music independently at a distance & 2.10 & 1.292 & 0.126 & 1.00 & 0.591 \\
\hline I would like to continue distance learning of music independently & 2.14 & 1.274 & 0.124 & 2.00 & 0.466 \\
\hline
\end{tabular}

Those students who enjoyed learning music independently at a distance also wanted to continue that $(\mathrm{r}=0.685 ; \mathrm{p}<0.01)$. The students wanted to continue learning music independently at a distance if they could print the learning materials sent by their teacher $(r=0.266 ; p<0.01)$. The study found that there is a significant difference between the attitude of 2 nd and 3rd grade students towards independent and distance learning of music $(\mathrm{F}=11.12, \mathrm{p}=0.001<0.05)$. The $3 \mathrm{rd}$ grade students expressed a more positive attitude towards independent distance learning of music than the 2 nd grade students did.

\section{Conclusions}

One of the study questions was to find out how independent the students are when they learn music at a distance. Students' independence is important to find the tasks sent by the teacher in the E-class, complete them and send them back to the teacher without asking for assistance from their parents. The study found that students' independence in finding the writing tasks in the E-class and performing them is at a middle level. It was easy for students to learn to sing songs independently and to complete tasks related to listening to music. The students at a high level assessed these types of musical activities. The study revealed that the 3rd grade students learn music more independently than the 2nd grade students. It is possible to conclude that primary school students are not yet fully prepared to learn music independently at a distance. They still have to acquire the skills needed for independent distance learning of music under the guidance of a teacher. 
The second study question identified the technical aids used by the students to learn music independently at a distance. The students mostly used computers and mobile phones while learning music at a distance. The majority of students believed that they had a lack of technical aids for learning. Many students were unable to print the writing tasks sent by the teacher as well as they faced difficulties in singing songs and listening to music. It should be concluded that one of the conditions for successful independent distance learning of music is the provision of technical aids.

The third study question recognized the difficulties the students faced in learning music independently at a distance. The students believed that the easiest part of learning was performing tasks related to listening to music. More difficult was to learn singing songs. That was probably due to insufficient singing skills, lack of motivation and shortage of technical aids needed for learning. The students had the most difficulty in completing the writing tasks because the possibility to print them was limited. That, in turn, did not motivate the students to independent distance learning of music. By printing the writing task in music, the students could spend less time to complete it.

The fourth study question determined the students' attitude towards independent distance learning of music. The study concluded that the students assessed their attitude towards learning music independently at a distance at a middle level. Many students missed the teacher's presence and longed for face-to-face music lessons.

The fifth study question tried to find out whether there is a difference between 2nd and 3rd grade students' the independence of learning music at a distance. The study revealed that there is a significant difference between 2 nd and 3rd graders in the ability to find the assigned tasks sent by the teacher independently. Moreover, the 3rd grade students would like to learn music at a distance more than the 2 nd grader.

\section{Bibliography}

1. Balapumi R., Aitken A. (2012). Concepts and Factors Influencing Independent Learning in IS Higher Education. In J. Lamp (Ed.), The Proceedings of the Australasian Conference on Information Systems (ACIS), 23. Geelong, Victoria: Deakin University. Retrieved from https://dro.deakin.edu.au/eserv/DU:30049160/balapumi-conceptsandfactors-2012.pdf

2. Candy P.C. (1991). Self-Direction for Lifelong Learning. San Francisco: Jossey Bass. doi: $10.1177 / 074171369204200307$

3. Chau J., Cheng G. (2010). Towards Understanding the Potential of E-portfolios for Independent Learning: A Qualitative Study. Australasian Journal of Educational Technology, 26(7), 932-950. doi: 10.14742/ajet.1026

4. Cukurova M., Bennett J., Abrahams I. (2018). Students' Knowledge Acquisition and Ability to Apply Knowledge into Different Science Contexts in Two Different Independent Learning Settings. Research in Science and Technological Education, 36(1), 17-34. doi: 10.1080/02635143.2017.1336709

5. Darnis S. (2020). The Influence of Communicative Method and Independent Learning Style to the English. Learning Outcomes: An Experiment Research to Primary Grade One Level. International Journal of Linguistics, Literature and Translation, 3(6), 201-207. Retrieved from http://www.ijllt.org/wp-content/uploads/2020/07/Paper-21-2020.3.6-The-Influence-ofCommunicative-Method-and-Independent-Learning-Style-to-the-English-Learning-Outcomes-AnExperiment-Research-to-Primary-Grade-One-Level.pdf

6. Deci E.L., Ryan R.M. (2008). Facilitating Optimal Motivation and Psychological Well-being Across Life's Domains. Canadian Psychology/Psychologie canadienne, 49(1), 14-23. doi: $\underline{10.1037 / 0708-5591.49 .1 .14}$

7. Gorman M. (1998). The 'Structured Enquiry' Is Not a Contradiction in Terms: Focused Teaching for Independent Learning. Teaching History, 92, 20-5.

8. Hughes P. (2014). Developing Independent \& Autonomous Learning. Retrieved from https://www.swansea.ac.uk/media/Mick-Healey-Independent-Learning-Workshop-Handout.pdf

9. Issa T., Issa Th., Kommers P. (2014). Feedback and Learning Support That Fosters Students' Independent Learning: An Australian Case Study. The International Journal of Learning, 19, 29-39. Retrieved from https://espace.curtin.edu.au/bitstream/handle/20.500.11937/29935/195723_104207_IJL_Feedbackan dLearningSupport_published_version.pdf? sequence $=2 \&$ isAllowed $=\mathrm{y}$

10. Katane I., Katans E., Vavere G. (2012). Environment of distance learning for humanization and democratization of education: the historical aspect. In V. Dislere (Ed.), The Proceedings of the International 
Scientific Conference Rural Environment. Education. Personality (REEP), 5. Jelgava: LLU, 35-42. Retrieved from https://lufb.llu.lv/conference/REEP/2012/REEP-2012-proceedings-E-ISSN-2255808X.pdf\#page $=36$

11. Kopzhassarova U., Akbayeva G., Eskazinova Z., Belgibayeva G., Tazhikeyeva A. (2016). Enhancement of Students' Independent Learning Through Their Critical Thinking Skills Development. International Journal of Environmental \& Science Education, 11(18), 11585-11585. Retrieved from https://eric.ed.gov/?id=EJ1121248

12. Lamb T. (2006). Supporting Independence: Students' Perceptions of Self-Management. In T. Lamb, H. Reinders (Eds.), Supporting Independent Learning: Issues and Interventions. Frankfurt-am-Main: Peter Lang Publishing, 95-122.

13. Martens R.L., Valcke M.M.A., Portier S.J. (1997). Interactive Learning Environments to Support Independent Learning: The Impact of Discernability of Embedded Support Devices. Computers \& Education, 28(3), 185-197. doi: 10.1016/S0360-1315(97)84657-X

14. Medne A. (2020). Par attālināto mācību procesu Gulbenes novada skolās [About the Distance Learning Process in Gulbene District Schools]. Retrieved from

https://www.gulbene.lv/lv/zr/izglzin/94-viz/7248-par-attalinato-macisanas-procesu-gulbenes-novadaskolas-2 (in Latvian)

15. Meyer B., Haywood N., Sachdev D., Faraday S. (2008). Independent Learning. Literature Review. Research Report DCSF-RR051. Nottingham: Learning and Skills Network. https://www.associationforpsychologyteachers.com/uploads/4/5/6/6/4566919/independence_learning lit_review.pdf

16. Opincāne E. (2020). Attālinātā mācī̌šanās: ieguvumi un izaicinājumi [Distance Learning: Benefits and Challenges]. Retrieved from http://rezeknesnovads.lv/attalinata-macisanas-ieguvumi-un-izaicinajumijeb-viss-ir-iespejams-ja-uzdrosinas/_in Latvian)

17. Reeves T.C. (1998). The Impact of Media and Technology in School. A Research Report prepared for The Bertelsmann Foundation. Athens, Georgia: The University of Georgia Retrieved from http://treeves.coe.uga.edu/Bertlesmann_Impact_Report.pdf

18. Ritchie L., Williamon A. (2011). Primary School Children's Self-Efficacy for Music. Journal of Research in Music Education, 59(2) 146-161. doi: 10.1177/0022429411405214

19. Shieh E., Allsup R.E. (2016). Fostering Musical Independence. Music Educators Journal, 102(4), 30-35. doi: 10.1177/0027432116645841

20. Sukowati S., Sartono E.K.E., Pradewi G.I. (2020). The Effect of Self-regulated Learning Strategies on the Primary School Students' Independent Learning Skill. Psychology, Evaluation, and Technology in Educational Research, 2(2), 81-89. doi: 10.33292/petier.v2i2.44

21. Sze Yean L. (2019). Promoting Active Learning and Independent Learning among Primary School Student Using Flipped Classroom. International Journal of Education, Psychology and Counseling, 4(30), 324-341. Retrieved from http://www.myjurnal.my/filebank/published_article/90243/6.pdf

22. Thornton L. (2020). Music Education at a Distance. Journal of Music Teacher Education, 29(3), 3-6. doi: $10.1177 / 1057083720928615$

23. Upitis R., Abrami P.C., Boese K. (2016). The Use of Digital Tools by Independent Music Teachers. In I.A. Sanchez, P. Isaias (Eds.), The Proceedings of the International Conference Mobile Learning, 12. Vilamoura, Portugal: International ASSN for Development of the Information Society (IADIS), 108-112. Retrieved from https://files.eric.ed.gov/fulltext/ED571442.pdf

24. Upitis R., Boese K., Abrami P.C. (2017). Student Experiences with a Digital Tool for Music Practice and Learning. The European Journal of Social and Behavioural Sciences. Volume XX, 2549-2560. doi: $10.15405 /$ ejsbs. 224

25. Wallace S. (Ed.). (2015). A Dictionary of Education ( $2^{\text {nd }}$ ed.). New York: Oxford University Press. doi: 10.1093/acref/9780199679393.001.0001

26. Whitebread D., Anderson H., Coltman P., Page C., Pino-Pasternak D., Mehta S. (2005). Developing Independent Learning in the Early Years. International Journal of Primary, Elementary and Early Years Education, 33(1). 40-50. doi: 10.1080/03004270585200081

27. Wicks D. (2008). Music Education and the Meaningful Use of Technology. Australian Kodály Bulletin. Grafton: The Kodály Music Education Institute of Australia Inc., 27-32. Retrieved from http://kodaly.com.au/assets/Australian_Kodaly_Bulletin_2008_LR.pdf

28. Zheng J., Xing W., Zhu G., Chen G., Zhao H., Xie C. (2020). Profiling self-regulation behaviors in STEM learning of engineering design. Computers \& Education, 143, 103669. doi: $\underline{10.1016 / j . c o m p e d u .2019 .103669}$ 